\title{
APPLIED BIOLOGY IN WAR-TIME
}

\begin{abstract}
A WELL-ATTENDED and representative meeting of the Association of Applied Biologists was held at Harpenden on December 6 under the presidency of Mr. C. T. Gimingham to discuss the function of applied biology in war-time. In the opening paper, Sir John Russell dealt with the three general groups of problems to which applied biology can usefully contribute: maintenance of public health during the War ; protection of food and other materials, for example, wood, flax, etc., both in the field and in store against deterioration by biological agents; and increase in the amount of food supplies.
\end{abstract}

While the maintenance of public health is primarily the business of the medical authorities, applied biologists can render valuable assistance in the adequate cleansing of shelters and of the persons and property of evacuated people. Much of the difficulty of finding accommodation in reception areas is due to the fear that insects and diseases may be brought from the cities into clean country homes, as actually happened in the first evacuation. It is, however, chiefly in connexion with food supplies that applied biologists are usually concerned, especially with food protection. The average dietary in Great Britain is both varied and attractive, but it cannot be maintained in war-time; a much simpler diet is necessary involving less meat, butter, eggs and sugar, but more potatoes, vegetables and bread. Of this new dietary we can produce far more than the 40 per cent of pre-war days : already the figure is well above this and will, it is hoped, be still higher. But the new programme necessitates the conversion of grass land to arable, and various members of the grass land population need controlling. Wireworms do much damage to wheat and other cereals. In the War of 1914-18 no adequate control measures were found, and unfortunately only a moderate amount of investigation was made in the peace period, so that we are still in much the same position as in 1918. Two fungi injurious to wheat have come into prominence since the War of 1914-18: Ophiobolus graminis and Cercosporella herpotrichoides : the former is harmful on light rather alkaline soils, and the latter is encouraged by the nitrogenous manuring now being enjoined on farmers. The potato crop is liable to a considerable number of pests and diseases, but some of the worst, for example Phytophthora blight and wart disease, can be dealt with. The virus diseases are now the most troublesome; fortunately they are now being vigorously studied. In the meantime they can be avoided only by the use of virus-free seed, but this is not always convenient.

For animals it is necessary to provide more protein equivalent, as the quantity produced on the farm tends to be reduced by ploughing out. Beans would furnish useful supplies, but are liable to attack by aphids. Marrow stem kale is an excellent transformer of simple and easily obtainable nitrogen compounds into protein equivalent, but it may suffer badly from the turnip flea beetle. Fuller control measures are desirable.

Considerable help has already been rendered, however, by applied biologists in saving crops and also the finished products milk and meat. Cleaner milk is now realizable in practice, and bacteriological control is understood and appreciated by many farmers ; while valuable service has been rendered in regard to the control of the sheep blowfly and the tick Ixodes ricinus, which causes louping in sheep. The storage of food presents numerous problems now happily far better understood than in the War of 1914-18.

The investigation of war-time problems will necessitate numerous studies and surveys which, it it hoped, will be so planned that the results can be subjected to statistical analyses. Little more trouble is involved, and the value of the work is greatly enhanced.

Two food production activities come within the scope of applied biologists. Honey production is capable of much expansion in Great Britain : already about one million pounds' worth is produced annually, but bees render even greater service than this in the pollination of fruit trees and certain other plants. The other problem is not so well advanced. During the War of 1914-18 the Germans were said to be using a yeast for the production of protein and fat for human consumption. It is hoped we shall not need to do this ; but it would be of the greatest value if some process could be worked out for synthesizing protein for animals. Suitable nitrogen compounds are available, but the substrate presents difficulties; various wastes might be used, but the ideal source of carbohydrate would be straw, which is available in particularly large quantities on most farms.

These are the main problems : the question is how best to organize the activities of applied biologists so as to ensure finding some solution now, and continuing the work after the present war is over.

In the discussion Prof. J.W. Munro, Mr.J.C.F. Fryer and others emphasized the fact that the war-time biological problems of to-day include many of those of the War of 1914-18, and if we had continued work on them during the past twenty years with the same impetus we should now have been in a much happier position. There was also the old difficulty of ensuring that existing knowledge should be fully applied in practice. Mr. Fryer instanced leather jackets, which had damaged thousands of acres of erops, and the white cabbage butterfly, which last year caused much loss, both of which could have been controlled. It was, however, more difficult to forecast outbreaks in Great Britain than on a Continental area. Mr. Findlay spoke of the serious wastage of sandbags because certain known precautions had not been taken.

It was strongly urged by Drs. Blackman, Ainsworth, Barnes and others that biological experts are not being fully drawn upon at the present time, and on the motion of Dr. Goodey and Mr. Fox-Wilson the Council of the Association of Applied Biologists was asked to bring to the notice of the appropriate bodies the pressing problems which exist to-day in applied biology and to discuss with them the means of utilizing to the best advantage the services of applied biologists. 